\title{
Students' Perceptions on the Quality of Teaching by Faculty at Jomo Kenyatta University of Agriculture and Technology in Kenya
}

\author{
Shadrack Muvui Muya \\ Department of Zoology, Jomo Kenyatta University of Agriculture and Technology, Nairobi, Kenya \\ Email address: \\ smuya@jkuat.ac.ke \\ To cite this article: \\ Shadrack Muvui Muya. Students' Perceptions on the Quality of Teaching by Faculty at Jomo Kenyatta University of Agriculture and \\ Technology in Kenya. Higher Education Research. Vol. 4, No. 1, 2019, pp. 1-15. doi: 10.11648/j.her.20190401.11
}

Received: August 8, 2018; Accepted: February 21, 2019; Published: April 18, 2019

\begin{abstract}
This study investigated students' perceptions on the quality of teaching between part-time and full-time faculty in Jomo Kenyatta University of Agriculture and Technology in 2015. The study examined students' understanding on quality teaching, faculty tenure statuses, and relationship between faculty tenure status and ability delivery quality teaching. These variables were measured using faculty's ability to delivery subject content, their accessibility, mentorship and extra-class communication to students. The typology of the research design was mixed-methods descriptive research design that allowed for collection of both qualitative and quantitative data. Findings from this study showed that a high number of students $(64.5 \%$, $\mathrm{n}=178)$ were able to differentiate between poor and good quality teaching, and an equally high number $(64.8 \%, \mathrm{n}=178)$ makes an effort to attend classes that they deem lecturers to offer high quality teaching. Majority of the students $(74 \%, \mathrm{n}=180)$ were able to distinguish between full-time faculty from part-time faculty. Students indicated that about $50 \%$ of the part-timers were either tutorial fellows or graduate assistants and they experienced a difference in performance between full-time and part-time faculty. $57.14 \%$ of the surveyed students indicated that full time lecturers cover syllabus and are better in content delivery compared to part time lecturers, however, $30.95 \%$ of the students indicated that they did not find any difference. While $61.90 \%$ of students indicated that full-time faculty are available for student's mentorship, only $7.14 \%$ of students indicated that part time lecturers participate in student mentorship. Only $2.38 \%$ of the students indicated that part-time faculty are available for extra class communication. In conclusion, majority of the students in JKUAT in main campus 2015 understood quality teaching. They were also able to differentiate between part-time staff and full-time staff. Students found teaching by part-time staff to be of low quality. Part time staff were poor in mentorship and not accessible to offer student after class communication. Thus, the presence of inexperienced and freshly graduated part-time faculty is a matter to worry about in relationship with quality teaching. This study recommends that Universities must find ways to improve the low quality teaching offered by part-time faculty. The study should also be extended to other Universities perhaps using explanatory research designs to improve its ability to discriminate the null hypothesis.
\end{abstract}

Keywords: Student Perception, Education Quality, Part-Time Faculty, Full-Time Faculty

\section{Introduction}

Quality teaching is the use of pedagogical techniques to deliver learning outcomes for students [1, 2]. It involves several dimensions, including effective design of curriculum and course content, a variety of learning contexts, soliciting and using feedback, and effective assessment of learning outcomes [3]. It also involves well-adapted learning environments and student support services. Fostering quality teaching presents Universities with a range of challenges at a time when governments are reducing funding to this sector. This matter has been made worse by massification of educational Institutions that end up draining the little funds available.

Faculties are engaged to teach on either part-time or fulltime tenure status. Part-time faculty are non-tenure track, interim employees, and adjunct professors [4]. Usually, they are recruited for a semester to teach particular Unit and do 
not have any other benefit apart from the monetary rewards offered for teaching the unit. Full-time tenure track members are permanent teaching employees [4] usually working at specific institutions on a continuous basis and receive salary, health and life insurance, leave, tenure, pension among other benefits. They also have tools of trade such as office and opportunities for further skills development at the cost of the employer.

Worldwide, faculty composition in terms of employment status is changing, with a steady increase of part-timers in recent years $[5,6,7]$. The part-timers serve as shock absorber to protect the permanent workforce from the consequences of student massification. This also enables the management to achieve "permanent flexibility" or a "disposable faculty" [8]. Usually, part-timers are not given opportunities to develop professionally [9]. Part-time lecturers face the insecurity of their employment relationship and the possible dilemma between the need to earn an income while attending to their personal development drives them to work in many places at the same time $[10,11]$. It is therefore interesting to investigate students' accessibility to lecturers with respect to their differential employment status. Accessibility is conceptualized as having two dimensions: physical accessibility, or the degree to which students view lecturers as being present and available for out of class interaction; and social accessibility, which refers to the degree to which students view lecturers as being socially available, or seem interested in informal interaction [12].

Societies have embraced the need to attain higher education as a basic strategy to exit from the vicious cycle of poverty and gain competitive advantage in the global market. This has raised demand for higher education worldwide rapidly. In the United States of America for example, student numbers have increase steadily throughout the years [12]. China doubled its student population in the late 1990s, India lags closely behind China while Kazakhstan, Bangladesh, Republic of Korea and Australia have also experienced increase in student enrolment in the same periods [13].

In Africa, has increased demand for higher education has yielded to institutional massification epitomized by the rapid growth in varieties of university institutions and student enrolment within a short period of time [14, 15]. The adoption of open and distance learning model has enabled several Universities to cope with the increased demand for education without expanding physical infrastructure in the University. The University of South Africa (UNISA) claims to be the continent's premier distance learning institution with approximately 250,000 students [16]. The African Virtual University works across borders and language groups in over 27 countries and has offered learning opportunities to a wide variety of learners and even the incarcerated. Social inequalities that are gender based and deeply rooted in certain African histories have stalled equal provision of higher education leading to skewed individual's ability to compete in the labour market. Initiatives in Ghana, Kenya, Uganda and the United Republic of Tanzania have lowered admission cut-offs for women to increase female enrolment.
This has also resulted to increase in the number of students in public Universities. In Kenya student enrolment has increased from 3,443 students in 1970 to nearly 200,000 in 2010 [17]. This rapid and sustained growth in demand for higher education in Kenya has consistently and certainly outpaced supply of quality teaching staff [17].

Jomo Kenyatta University of Agriculture and Technology (JKUAT) is a Public University chartered by the Commission for University Education under the Universities Act 2012 No 42. It has over 50,000 student population. To optimize effective student/faculty ratio, the University has been engaging part-time faculty services. This is not unique to JKUAT as it happens to many Universities worldwide [4, 18]. Part-time faculty provide readily available labour [19], but the quality of their teaching is debatable.

The purpose of this study was to investigate students' perceptions on quality of teaching by faculty under varied tenure track in JKUAT. Key questions focused by this study include what do students perceive as good quality teaching? Are students able to differentiate faculty members on the basis of their tenure statuses? Finally, what is the effect of a staffs' tenure status on their teaching quality as measured in their ability to delivery content, accessibility to students, ability to mentor student and participation in extra-class communication?

Limitations experienced in this study included failure by some students to respond to a number of items in the questionnaire, especially the qualitative section, while some never respond at all. In the Campus, the major limitation was that some programs are mounted only on weekends or at evening and student had little time to participate in the interview. Another limitation experienced in this study was delay in response to the questionnaires by some students while a batch of questions for students in engineering department got lost and had to be replaced.

\section{Literature Review}

\subsection{Student's Perception on Good Quality Teaching}

\subsubsection{Theoretical Basis of Quality Teaching}

The term perception implies conscious understanding and interpretation of a phenomenon. Since previous experience play a key role in interpretation of occurrences, it is important to understand the key theories that form the basis of quality teaching. These theories are universal and form the basis of understanding students' perception on quality teaching. The practice of teaching is considered to be a type of manufacturing system, which should be established on the basis of relevant theories [20]. Three basic theories of quality teaching practices forms the basis of this study. They include theory of all-round educational quality, the stage theories of higher education development, and the theories of the inner and outer law of education.

a) Theory of All-Round Educational Quality.

The implementation of all-round quality management began in western development countries since the early 90 s, 
and now it is developing quickly $[21,3]$. The all-round quality education is the application of all-round quality management in the area of education. It means that an organization, which is based on full participation, treats quality as its centre. All members will benefit from this organization, and thus the organization will achieve longterm success. As the continued expansion on the concept of education quality, the quality of education is not only to train students to possess knowledge, but also to help them have other various qualities, such as working attitude, sense of cooperation and competition, professionalism, moral cultivation, environmental adaptability and mental endurance capabilities [22]. Therefore, all-round quality management is not only a philosophy, but a method. All-round quality management involves all activities in the school and it is related to everyone. To guarantee all round education quality, the faculty should be available to deliver subject content, be accessible to students, mentor them and avail extra-class communication. This will require a comprehensive management program.

b) The Stage Theory of Higher Education Development

This theory was proposed by Professor Martin Trow at the University of California. He describes the transition in higher education from elite to mass to universal student access [23]. Professor Martin Trow points out that there is a fundamental change from elite to mass, which doesn't only mean a sharp increase in the number of people who can receive higher education, but a change in quality which plays an important role in the transition from elite to mass. The quality refers to the change of education concept, expansion of the function of education, diversity of teaching purposes and forms of Education, and the change of curriculum set-up, the way of teaching, entrance requirement and management. In Kenya, this theory applies and it's important to find out whether employment status does affect the quality of teaching.

c) Theories of the Inner and Outer Law of Education

As a social activity, education must follow the law. Among all laws, there are two most basic laws. One is the law of relationship between education and social development, which is called the inner law of education [20]. This law holds to the idea that education is a subsystem in the whole social system, which has an inevitable connection with other subsystems, like economy, politics and culture. Therefore, this kind of law can be further explained in the following way: "education is limited by social economy, politics and culture; in turn, education can stimulate development in education, culture and economy"

The other law is about the relationship between education and human beings, which is called outer law of education. This law believes that many factors will affect the learners during the process of education. Two points should be noted in the relation between education and the development of human beings (including employment status): the first one is that the relation of each composing part in the comprehensive development of human being should be noted, and the second fact points out that among all composing parts, the relations between educators, educational objects and related influencing factors are the most basic. The relationship between the inner and outer laws of education is that the inner law of education is limited by the outer law, while outer law of education can only be done through inner law. Quality teaching is limited by the inner law of education, while employment status is limited by the outer law. In other words, social background must be taken into account in understanding the quality of education [20]. It is necessary to measure the quality of education from the aspects of social background, economy, politics, culture and other specific environment.

The large-scale development of education in Kenya is necessary to meet the need of high-level personnel needed in this country. To explore the problems of quality education based on the outer law of education, it important to understand the historical background of society, economy, technology and education and how these factors influence employment status of the teaching staff in relationship education massification.

\subsubsection{Illustrations from Unstructured Feedback Studies}

Previous studies based on unstructured feedbacks have demonstrated students' competence in understanding quality teaching. Drawing from their own experiences as postsecondary students, participants were asked to identify five characteristics of effective teaching, for both on-campus and distance courses, describe these characteristics, identify instructor behaviours that demonstrate the characteristics, and rate the characteristics in order of importance [24]. The survey instrument provided allowed students to identify characteristics that they believe are important to effective teaching, rather than simply agree or disagree with a set of prescribed characteristics. 330 students completed the survey. Data was coded manually and 69 adjectives were identified that students used to describe characteristics of effective teaching. These definitions and behaviours were analysed further by grouping of the data along behavioural themes and nine characteristics of effective teaching were identified. Effective university teachers at Memorial University are: respectful, knowledgeable, approachable, engaging, communicative, organized, responsive, professional, and humorous [24]. This is a clear example to illustrate that student can differentiate high quality teaching from sloppy engagements.

Findings from this study compare favourably to the standard Tripod surveys of quality teaching common in USA, UK and China. The primary measures of instructional quality in the Tripod surveys are gathered under seven headings called the Seven C's [25]. The seven are: Care, Control, Clarify, Challenge, Captivate, Confer and Consolidate. The Seven C's are grounded upon a great deal of education research by many researchers over the past several decades. They capture much of what researchers have suggested is important in determining how well teachers teach and how much students learn. Each of the C's is measured using multiple survey items. However, according to McNaught, Leung, \& Kember [26] teaching and learning environment 
also influences the development of student's generic learning capabilities.

\subsubsection{Illustrations from Structured Feedback Studies}

Structured feedback studies have been used extensively to demonstrate that students in institutions of higher learning are competent enough to differentiate quality teaching from poor quality teaching $[25,24,27]$. In these studies, structured feedback on the seven key competencies of a quality teacher have being analysed. The seven key competencies include interpersonal skills, pedagogical skills; mastery in subject matter and teaching methods, organizational skills, competence to cooperate with colleagues, competence to cooperate with the school's working environment and competence for reflection and development. Student feedbacks are good tools to measure these teaching qualities; after all, no one knows more about what happens in classrooms than the students and teachers who inhabit them [25].

The practice of asking students to provide feedback on the quality of a teaching episode during a particular academic year has sufficed in many institution of higher learning for a long period; especially in Europe and America. Several studies have demonstrated that students are capable of evaluating the quality of a teaching period and effectively judge whether it was of high or poor quality [25, 24, 27]. In 2008, Memorial University of Newfoundland students were asked in an online survey to provide their perceptions of effective teaching for both on-campus and distance instruction through the use of an open-ended survey instrument. This was a deviation from previous studies that used Likert scale questionnaires, or controlled sets of stimuli such as the 32 teacher profiles used in Ralph's [28] study.

\subsection{Student's Awareness on Faculty Employment Statuses}

\subsubsection{Academic Titles and Employment Statuses}

In the United States, academic staffs are classified according to titles, the functions or powers the personnel holds in academia [29]. An academic title is a designation given to individuals who is engaged in teaching of credit courses, academic research, or professional library service. Generally a title is relied on to convey three attributes of its holder: rank (level of appointment), status (Regular Faculty or otherwise) and function (Teaching, Clinical, Research, etc.). The title may also carry an Honorific status, such as "Distinguished," as mark of special recognition. This much was recognized by Gilbert [30] in referring to The Mikado's Lord High Executioner as "a personage of noble rank and title," making it clear that rank and title are different. "Lord" conveys nobility; "High" specifies rank; "Executioner" defines function [29].

While this trichotomy is fairly logical, there is much confusion in practice between the concepts of "title" and "rank." Title is the name by which an academic position is known, e.g. "Associate Professor of the Practice of Surgery." Rank refers to the holder's position in an ordered promotion sequence known as a Series. The fundamental Series in US institutions is - Instructor, Assistant Professor, Associate Professor, Professor, which are listed in order of increasing rank [29].

In the United Kingdom, like most Commonwealth countries (excluding Australia and Canada), as well as in Ireland, academic ranks include Professor, Reader (A rank abolished in some Universities such as Oxford, Leeds) or Associate Professor, Senior lecturer, or senior teaching fellow, Lecturer, or clinical lecturer, or teaching fellow and demonstrator [31]. Traditionally a professor held either an established chair or a personal chair. An established chair is established by the university to meet their needs for academic leadership and standing in a particular area or discipline and the post is filled from a shortlist of applicants; only a suitably qualified person will be appointed [32]. A personal chair is awarded specifically to an individual in recognition of their high levels of achievements and standing in their particular area or discipline. General in the UK the title of 'professor' is reserved for full professors or Associate Professor; lecturers and readers are properly addressed by their academic qualification (Dr for a PhD, DPhil etc., and Mr/Mrs/Miss/Ms otherwise for other qualifications.

In most universities in Australia, New Zealand and South Africa, professorships are reserved for only the most senior academic staff, and other academics are generally known as 'senior lecturers' and 'readers' (in some Commonwealth countries such as, the title 'associate professor' can be used instead of 'reader' [31] ) and 'lecturers'. In some countries, senior lecturers are generally paid the same as readers, but the latter is awarded primarily for research excellence, and traditionally carries higher prestige. Traditionally, heads of departments and other senior academic leadership roles within a university were undertaken by professors. [33]. The University of Western Australia has recently changed the terminology, with "lecturers" now being called "assistant professors", "senior lecturers" now being called "associate professors", "associate professors" now being called "professors", and "professors" now being called "Winthrop Professors" [34]. Most Commonwealth countries; Kenya included academic ranks in most Universities are Professor, Associate Professor, Senior Lecturer, Lecturer, Tutorial Fellow and Graduate Assistant. However, the ranks have no implications on the tenure status of the holder of the title and students cannot use the titles to differentiate between fulltime and part-time faculty.

In academia, the term "Tenure" is commonly used in Northern America and it basically means the status granted (after a probationary period) to a Ranked Faculty member protecting him or her from arbitrary dismissal [29]. Tenure gives the faculty member the contractual right to be reemployed for succeeding academic years until he or she resigns, retires, is dismissed for cause, is separated pursuant to a reduction in force, or becomes disabled or dies. In Kenya, it is similar to permanent and pensionable employment commonly enjoyed by lecturers and above. Tenure track refers to a promotion sequence leading ultimately to the award of tenure provided that the incumbent 
continues to meet progressively more stringent criteria for advancement, and therefore a tenure track position is one which may lead to consideration for appointment to tenure. In Kenya, Graduate Assistant and Tutorial Fellows are contract positions that lead to permanent after one has acquired a $\mathrm{PhD}$ and hence they are tenure track positions. Adjunct faculty are those untenured academic staff who have instructional duties but are not on a full-time faculty contract. They are also called part-timers. They may have the same academic qualification as the full time staff, or even higher, but are employed on part-time basis for various reasons.

Previous studies in Canada have shown that students have the competence to profile staff on the basis of tenure structures [35]. A study by Bippus, Brooks, Plax, \& Kearney [36] shown that faculty employment status is not a salient issue to students. There are not many studies in Kenya on the competence of students to profile faculty on tenure status.

\subsubsection{The Adjunct or Part-time Faculty}

Identifying who is a part-time faculty is difficult because the staffs that fall under this category come under different titles and ranks. In the UK, they are referred to as sessional staff. In Northern America, they are referred to as adjutant tenure and in Kenya they are called part-timers. They have a host of titles and ranks, such as visiting lecturer, teaching assistant, hourly paid lecturer or graduate teaching assistant. They include Postgraduate students (could be part-time), Graduate teaching assistants, Early-career researchers, persons carrying out another main role in the university (e.g. research, technical, administrative, library/information systems), persons with a full-time (usually professional) role outside the higher-education institution, former senior professional practitioners who have retired, portfolio combinations including multiple teaching roles/working for multiple employers, a freelance/consultancy, a part-time secondary role (possibly low- paid, but offering a morecertain income). Others have the part-time as their sole employment while other are semi-retired former academic staff [37].

Major factors that determine who is recruited include the task and who is available locally - the insecure contract and level of reward make this a distinctly local labour market in the main, and the recruitment process is frequently "casualised" and informal too [38]. Thus in researchintensive universities a plentiful supply of postgraduate research students and contract researchers results in their making up a large proportion of sessional staff [39].

The trend in human resource procurement practices in Higher Education Institutions (HEIs) worldwide is towards the engagement of part-time faculty. This is partly explained by the pressure on higher education institutions to reduce costs [40, 41, 42, 7]. A large number of post-secondary institutions are currently struggling financially and are frantically trying various options to reduce their costs in view of consistent declines in their funding from central Government. Between 1970 and 2003, the number of parttime and full-time faculty in the United States of America, for example, increased by $422 \%$, and $71 \%$ respectively [21]. This implies that for every 1 full-time staff, there were 6 parttime faculty members. Similar statistics are also available for the United Kingdom, [43, 44], other European countries [45], and in Australia [46]. These statistics imply fact that parttime faculty make a large proportion of temporary workers in the developed world and perhaps it is a clear indication that casualisation is here to stay [38].

In Kenya, Universities are on record as employing a large number of part-time academic staff [47]. The Vision 2030 stipulates improved education status and availability as key ingredient in supporting the key pillars of the vision [48]. Since demand for faculty member outstrips supply of fulltime faculty staff, Universities are forced to hire part-time faculty to mitigate the gap. Student may not even differentiate full-time staff from part-time as Mwiria and Carey [49] notes that half of the teaching staff in the private universities is currently part-timers drawn from the public universities. Thus because of the high mobility involved in part-time teaching in various places, full-time staff in public Universities resemble their part-time staff.

There is also the possibility that part-timers either have low effect on student learning or negatively impact student outcomes [50]. This is especially demonstrated in units with research project where students require experienced staff to the supervise them. Students find the part-timers inaccessible to supervise them. In the end the students end up working with the few full-time staff available in the University. At this juncture student are able to differentiate faculty members on the basis of their employment status.

\subsection{Effect of Staff Employment Statuses on the Quality of Their Teaching}

\subsubsection{Historical Origin of Quality Assurance in Higher Education}

Quality assurance practices can be traced far back in history to the medieval Universities of Paris and Bologna where students initially formed guilds to protect their mutual interests and maintain standards [51]. The students made professors accountable by collectively putting their masters under bond to live up to a minute set of regulations which guaranteed the students the worth of the money each student paid. If a professor failed to secure an audience of five students for a regular lecture, he was fined as if absent [52]. Even though the mediaeval Universities had no libraries, laboratories, museums, no college journalism, and no athletics (as is today), higher education of the twentieth century is the lineal descendant of the mediaeval Universities [52]. The historic commitment to maintain standards of institutional quality and accountability, particularly with regard to program review, evaluation and assessment, has been passed down unbroken to the modern Universities [51].

Princes and Popes controlled the institutional standards of the mediaeval Universities by granting charters, thereby, officially creating generalized study and extending to masters and students special privileges including exemption from taxation, from military service, and from trial in courts of 
civil magistrates [53]. Papal bulls further enlarged the privileges of universities gave them apostolic sanction for the right to suspend lectures and ratify their authority to make their own statutes [54]. Resultantly, even though princes and popes controlled institutional standards, through charters, their sanctions expanded the power and afforded the medieval institutions greater control over their internal program review, evaluation and assessment [51].

\subsubsection{Role of Employment Status in Enhancing Faculty Commitment}

Several studies have documented faculty commitment to work with respect to the statuses of their employment [5563]. Borchers \& Teahen [56] studied organizational commitment by full-time and part-time academics in the US and observed no significant difference between the two groups. Similarly, student transfers out of the college to other colleges were independent of increase the number of parttime faculty [58], suggesting that students as key stakeholders in education sector were not affected negatively by increases in numbers of part-time faculty. In Europe, Shaw and Ogilvie [57] studied the effect of part-time work by students on undergraduate student learning in UK, and established that part-time working by students can enhance learning in colleges.

Bryson and Blackwell [60] studied the effect of hourlypaid part-time faculty in the UK higher education sector to establish whether it had any effects on strategic value addition. The study found out that differentiation in the workforce through the inclusion and use of part-time academics failed to address the aspirations of employees. It also created tensions between institutional strategy and the needs of academic heads [60]. This study highlighted existence of numerous categories of part-time academics engaged in UK [7].

Studies carried out in Asia and Australia seems to render more specific focus on the debate on quality of teaching by part-time academics. Chunghtai and Zafar [62] set out to determine if organizational commitment and quality of teaching by faculty staff in Pakistan University was related to their personal characteristics. Although the findings indicated that personal characteristics had significant effects on work commitment, the inclusion of other factors relating to distributive and procedural justice caused the findings to have limited application as a basis for further studies [7]. The study, however, made a considerable contribution by the fact that it identified and isolated personal characteristics of university academics as variables worthy of a study as affecting organizational commitment and quality of teaching [7].

In Africa, studies have pointed out that student evaluations of teaching quality (SETQ) programmes were not as common as it is in the west [64], and when carried out, they are not as comprehensive; sometimes it is out of a member of faculty effort to find out students' opinion about their course. In Nigeria, Ura [64] found that SETQs were not common and when done, sometimes feedback was not ploughed back the teachers. She suggested that these programmes should be introduced in all Higher Education Institutions as they would generally improve the learning experience - faculties, learning resources, human resources etc. In Uganda, Menya [65]pointed out that the major problem with education in Africa is quality, yet donors are more concerned with quantity. He observed that quantity education of low quality has less impact in Africa's development agenda. The role of faculty members in quality control is highlighted and viewed as key factor in quality management.

\subsubsection{Effects of Employment Status on Faculty Job Satisfaction}

Several studies have being carried out in Kenya on effect of faculty staff tenure status on organizational commitment and job satisfaction [66-69]. They all agreed that tenure status impact on the quality of teaching in that part-time faculty staffs have low commitment to the organization and their level of satisfaction is based the efficacy of the institutions in processing their payments. Indeed, some staffs are on record of having to hold on exams scripts and marks until their payments are processed. This is serious indicator of lack of job satisfaction and may easily translate to low quality teaching practices.

Generally, five factors affect the quality of teaching in higher education institutions [67]. They include the Government and commission of higher education; Human Resource Manual (HRM) as a tool for quality; Staff continuous professional development; effect of teaching facilities on quality of human capital and the challenges encountered on maintaining quality human capital at universities

This study examined content delivery, faculty accessibility, student mentorship and extra-class communication as measure of quality teaching by faculty. It also examined whether employment status influence any of the teaching quality measures in any way. Of particular interest to this study is how the reality of part-timers; which for many of them may include working at multiple institutions, inadequate office space, and lack of access to faculty "perks" such as course load reductions, may affect the frequency and quality of their interactions with students. This study examines students' perceptions on teacher's ability to deliver content, their accessibility and their belief that they will get useful mentorship, as well as students' likelihood of pursuing extra-class communication (ECC) with their lecturers, as related to faculty employment status.

\subsubsection{Role of Quality Assurance Systems in Monitoring Staff Performance}

In Kenya, most universities have established quality assurance systems, as a regular self-evaluation activity under total quality management approaches [7, 67]. The programmes use engagement questionnaires to evaluate student's perceptions on their development of important capabilities, and their perceptions on the teaching and learning environment. Students' perceptions on teaching quality is used in a diagnostic fashion to 'triggers' 
discussions with teaching staff in order to enable clear identification of strengths and challenges the staff is facing in offering quality teaching, and forming the basis for follow-up activities. The reviews have also been used in programme revisions to enhance the quality in teaching.

In JKUAT, there is an established Directorate of Academic Quality Assurance (DAQA) whose main function is to monitor academic programmes and ensure quality adherence. The directorate uses closed ended structured questionnaires to evaluate student's perceptions on their development of important capabilities, and their perceptions on the quality of teaching and the learning environment in the University. The questionnaires are administered in hard copy, but the directorate is going online. There is always a feedback mechanism to the teaching Departments.

The Commission for University Education (CUE) monitors the standards in both public and private Universities to strengthen quality assurance. This entails effective monitoring of curriculum development, implementation and evaluation. Therefore the role of students in identifying quality teaching practices is central in the process of quality assurance since they are the users of quality education and should be able to confirm its delivery.

\section{Research Methodology}

\subsection{Research Design}

A mixed-methods descriptive research design approach was adopted in this study because, descriptive research can be either quantitative or qualitative [70] and is appropriate for observational, case study or survey studies. Data from the registrar of academic affairs office formed the sampling frame population. The sampling frame focused on students in $2^{\text {nd }}$ to $5^{\text {th }}$ years of study because these students have already experienced teaching from both full-time and part-time faculty and hence understand quality teaching. Sampling took place in JKUAT Juja Campus in 2015 January-April Semester.

\subsection{Sample Size}

In this study, categorical data collected was not used to play any primary role in data analysis and therefore the sample size formulae for continuous data as described by Cochran [71] were used to calculate sample size. In the calculation, the alpha level was set at 0.05 , and a four point Likert's scale was used to produce a forced choice measure to avoid possibilities of indifferent opinion i.e., neither agree nor disagree [72]. The level of acceptable error was set at $3 \%$. This is because Krejcie \& Morgan [73] had demonstrated that a $3 \%$ error level is generally acceptable margins of error in educational and social research. The standard deviation (SD) was calculated from the estimate of variance deviation for the five point scale calculated by using 5 [inclusive range of scale] divided by 6 [number of standard deviations that include almost all (approximately 98\%) of the possible values in the range; three from each side of the spread [71]. From these computations, a sample size of 119 students was determined.

Students were asked to complete a self-administered questionnaire that contained both qualitative and quantitative questions in two distinct section. Qualitative questions were open-ended and facilitated unusual responses that were unlikely to get considerations in designing the scaled quantitative questionnaire [74]. Ten questionnaires were pretested to ensure that every survey question measured what it should measure and that respondents understood all the terms in the questionnaire and those that caused confusion were revised. Reliability tests were undertaken to check on any unusual cases, using Cronbach's Alpha based on standardized items.

\subsection{Data Analysis Methods}

Unstructured qualitative data was analysed using inductive thematic analysis approach [75]. Data that fell into similar thematic categories was then grouped together and assigned codes. Descriptive statistics were used to report the central tendency in both the coded qualitative and quantitative data. Absolute means and percentages of the respondents were used to summarize student's perception per research question. Factor analysis procedures were used to uncover relationships amongst several variables that were highly correlated. Finally an overall perception was arrived at by pulling together respondents' opinions on the quality of teaching between part-time and full-time faculty in JKUAT from the three research questions.

\section{Results}

\subsection{Qualitative Survey Findings}

\subsubsection{Students' Perception of Good Quality Teaching}

A large number of students $(74 \%, n=42)$ said that they do have memory of good learning experiences of which $45 \%$ of the good memory was described using cognitive dimension, $24 \%$ of the responses were described using emotional dimension and $32 \%$ of the responses contained a social dimension. $12 \%$ of the respondents said they do not have any memory of good learning experience while $14 \%$ of the respondents did not give an answer. All the students $(100 \%, n=42)$ explained that a quality teacher should ensure that content information is correct, is delivered properly and is understandable to the learners. $41 \%$, of the students $(\mathrm{n}=40)$ felts that achieving desired teaching outcomes was more important than how teachers prepared or what they brought to the teaching processes. Majority of the students $(74 \%, \mathrm{n}=42)$ did not know the difference between Professor, Associate Professor, Senior Lecturer, Lecturer, Tutorial Fellow and Graduate Assistant, 24\% of the respondents $(n=42)$ knew the difference and described it as the level of education and experience.

\subsubsection{Effect of Faculty Tenure Status on Their Performance}

This research question sought to find out the effect of 
faculty tenure status on their performance was measured in terms of faculty under varied tenure status's ability to delivery content, accessibility to students, ability to mentor student and participation in extra-class communication. $57 \%$ of the respondents indicated that full time staff are better in content delivery, $62 \%$ of the respondents indicated that full time staff are more accessible as they have offices where they can be located in the University, $55 \%$ of the respondents indicated that full-time faculty participate more in student mentorship and $57 \%$ of the respondents indicated that full time faculty are able to hold extra-class communication with students (Figure 1). In overall full-time faculty had a higher performance compared to part time faculty.

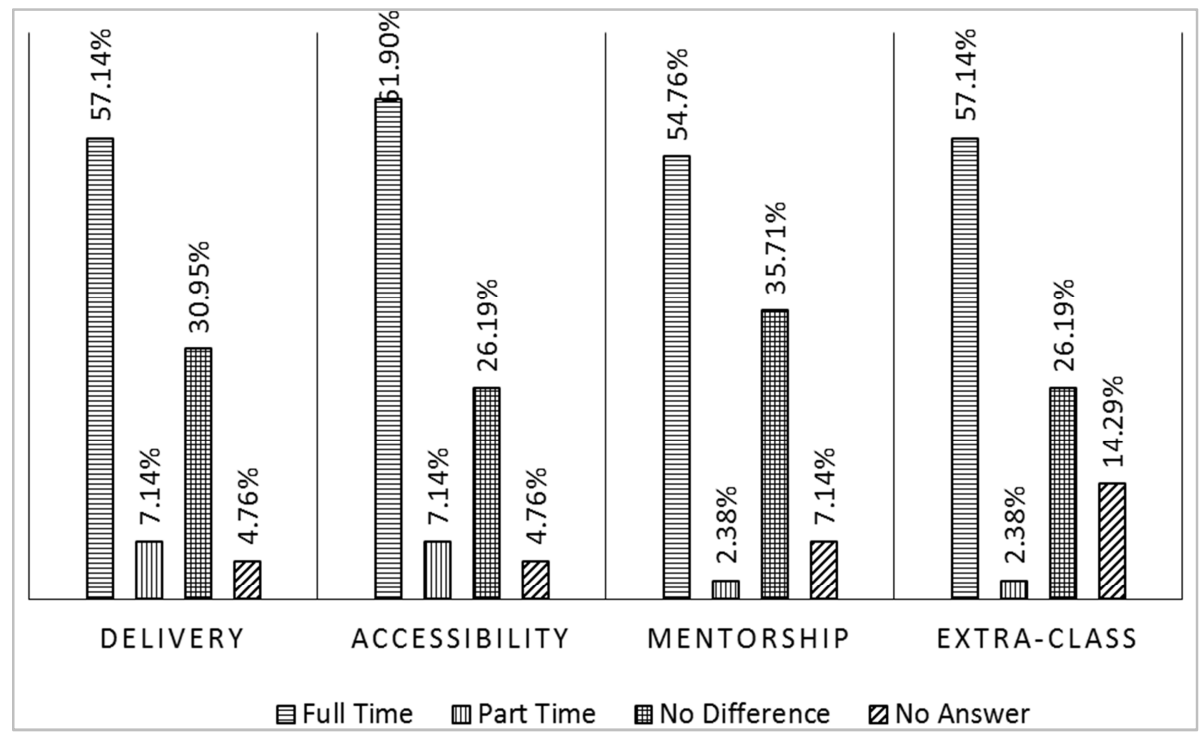

Figure 1. Effect of Staffs' Employment Statuses on Their Performance.

\subsection{Quantitative Survey Findings}

\subsubsection{What Students Recognize as Good Quality Teaching}

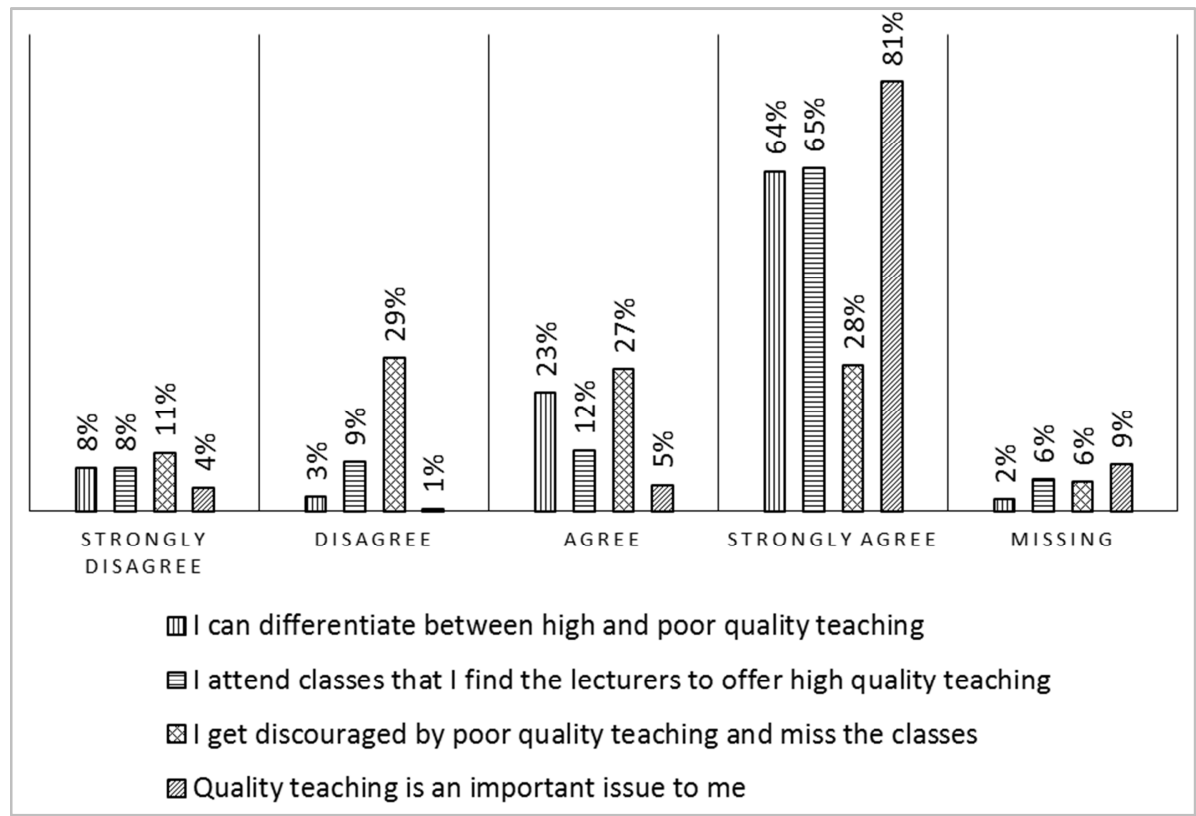

Figure 2. Summary of Responses of Question A1 - A4 of Quantitative Questionnaire.

In a scale of 1 (strongly disagree) to 4 (Strongly agree), $64.5 \%$ of the students strongly agreed that they could differentiate between high quality from poor quality teaching $(\bar{x}=3.46 \pm 0.07$ SEM, $\mathrm{n}=178)$. Although majority of the students $(64.8 \%)$ makes an effort to attend classes that they find the lecturers to offer high quality teaching $(\bar{x}=3.42 \pm$ 0.08 SEM, $\mathrm{n}=171)$, consensus was low when the question was reversed to find out whether students get discouraged by poor quality teaching and opt not to attend the classes; with an outright slim majority of $29 \%$ disagreeing that they are 
discouraged by poor quality teaching to the extent that they opt not to attend the classes, ten students did not answer this question. A clear majority of students (81\%) strongly agree $(\bar{x}=3.79 \pm 0.05$ SEM, $\mathrm{n}=166)$ that quality teaching is an important issue to them, and therefore majority of the students $(56 \%)$ strong disagree $(\bar{x}=1.77 \pm 0.08$ SEM, $\mathrm{n}=$ 167) that they never fill evaluation questionnaires to assess lecturers' teaching competence (figure 2).

Students are concerned about quality teaching. A majority of the students $(56 \%)$ strongly disagreed that they do not participate in various University activities aimed at evaluating lecturer's performance $(\bar{x}=1.77 \pm 0.08 \mathrm{SEM}, \mathrm{n}=$ 167). While $47 \%$ agreed that quality teaching initiatives are very diverse both in nature and in function, 38\% disagreed; a fairly close call in difference $(\bar{x}=2.48 \pm 0.05$ SEM, $\mathrm{n}=163$, with $10 \%$ of the students not answering this question. A slim majority of the students (36\%) disagreed with the suggestion that it is only lecturers who determine the quality of teaching done in JKUAT. This percentage was even higher $(60 \%)$ when the percentage of those students who strongly disagreed (24\%) with this suggestion was added to that of those who disagreed. Finally $50 \%$ of the students strongly agreed that quality teaching is an important issue in improving higher education $(\bar{x}=3.29 \pm 0.07$ SEM, $\mathrm{n}=168)$; actually those who agreed and those who strongly agreed pooled together formed $74 \%$ of the respondents with $8 \%$ missing to answer this question, meaning that a clear majority of the students felt that quality teaching is an important issue in improving higher education.

Stakeholders are increasingly demanding value for money and student's regard quality teaching primarily as an outcome, others as a process. Pooled together, the percentage of those students who agreed and those who strongly agreed with the suggestion that stakeholders are increasingly demanding value for their money formed $75 \%$ of the respondents. The suggestion that some students regard quality teaching primarily as an outcome, others as a process received substantial support, with $43 \%$ of the respondents agreeing to this suggestion and $37 \%$ strongly agreeing. The suggestion that quality teaching can never be totally grasped and appraised seemed to receive mixed responses with about $44 \%$ pooled responses in disagreement and about $46 \%$ pooled responses in agreement, however a pooled majority of the respondents (37\% agree and 36\% strongly agree) felt that quality teaching means different things to different stakeholders.

\subsubsection{Students' Awareness on Faculty Titles}

Students had difficulties in differentiating faculty titles and the basis on which different titles are conferred to specific faculty positions. A slim majority $(34.1 \%, \mathrm{n}=180)$ agreed that they know the difference between Professor, Associate Professor, Senior Lecturer, Lecturer, Tutorial Fellow and Graduate Assistant. Summing up those who just agreed together with those who strongly agreed formed 59\% of the respondents implying that majority of the students understands the difference between different faculty positions. Although a slim majority $(38.5 \%, \mathrm{n}=159)$ strongly agreed that all Professors have $\mathrm{PhD}$, pooling together the percentage all respondents who agreed to this suggestion indicated that $72 \%$ of the respondents agreed that all professors have a $\mathrm{PhD}$. Pooled together those respondents who agreed to the suggestion that the title of 'professor' is reserved for full professors or Associate Professor; lecturers are properly addressed by their academic qualification (Dr for a PhD, DPhil etc.) and $\mathrm{Mr} / \mathrm{Mrs} / \mathrm{Miss} / \mathrm{Ms}$ for other qualifications showed that majority of the respondents $(68 \%)$ were in agreement.

Students know faculty tenure status and qualification they hold. A majority (59\%) strongly agreed that Graduate Assistants are allowed to teach and examine students. A clear majority of the students $(62.6 \%)$ strongly disagree that there are no part-time faculty in JKUAT, however, a slim majority (33.5\%) strongly disagreed that Professors and other $\mathrm{PhD}$ holders cannot teach on part-time basis. A slim majority (31.9\%) strongly disagree that they have always being taught by part-time lecturers. These findings imply that the parttime faculty in JKUAT is mainly composed of staff of lower qualification.

It is easy to get faculty member in JKUAT, and the ease is similar between part-time and full-time faculty. In general the difference in opinion between the percentage of those who strongly disagreed and those who strongly agreed with the questionnaire was very close. However, when the percentage of all those who strongly agree and that of those who just agreed was pooled together and vice versa, clear opinions emerged. A combined $56 \%$ of the respondents disagreed that full-time and part-time staff are equally difficult to find in the University for consultations, while combined $63 \%$ disagreed that full-time staff are more difficult to find in the University consultation compared to part-time staff, but a combined $54 \%$ of the respondents agreed that part-time staff are more difficult to find in the University for consultation compared to full-time staff. .

\subsubsection{Students' Opinion on Performance of Faculty on Different Employment Statuses}

Students knew the full-time and part-time lecturers teaching them in the January-April 2015 semester since majority of them $(74 \%, n=180)$ agreed that they knew all full-time lecturers teaching them in that semester. Majority of the student $(62 \%)$ agreed that they knew all part-time lecturers teaching them in the said semester. A slim majority $(29.7 \%)$ of the respondents agreed that full-time lecturers deliver subject content better than part-time lecturers. Neither the total respondents who agreed to this suggestion nor those who disagreed managed to be over $50 \%$ of the respondents. This implies that students could clearly differentiate the faculty teaching into part-time and full-time, but there were no clear majority in determining the faculties' ability to deliver content.

Majority of the students $(63.2 \%, \mathrm{n}=180)$ found it access full time lecturers compared to part-time lecturers, though only $37.9 \%$ agreed that they knew the offices of all full time 
lecturers teaching them the said semester. This means that somehow they can reach the full-time faculty even though they do not know their offices.

Full-time faculty participated participate more $(67 \%, n=$ $180)$ in student mentorship through research supervision compared to part-time faculty. They were also more available $(70 \%, \mathrm{n}=180)$ for extra-class communications. This implies that part-time faculty do not participate in a major way in student mentorship and are not available in a major way for extra-class communication functions.

A majority $(66 \%, n=180)$ of the students disagreed that part-time lecturers are well prepared for classes. A clear majority $(52.2 \%)$ strongly disagreed that part-time lecturers do not mark and return assignments to students, although a pooled percentage of those who strongly agreed and those who just agreed showed that a majority of the students $(62 \%)$ agreed that part-time lecturers do not give all assignments indicated in course outline.

Students of suggested interventions that can improve performance by part-time lecturers and enhance the quality of their teaching. Majority of the students (52\%) agreed that part-time lecturers should be exposed to continuous professional development programmes. A pooled percentage of those who strongly agreed and those who just agreed indicated that majority of the students $(70 \%)$ agreed that the University should put in mechanism to monitor teaching by part-time lecturers. Similarly a majority of the students (70) strongly agreed that in order to enhance quality teaching, the focus of quality teaching should encompass the whole institution and the learning environment.

\section{Discussion, Conclusions, and Recommendations}

\subsection{Discussion}

\subsubsection{Students Perception on Quality Teaching}

Majority of the students in this study agreed that they have memory of quality learning experiences. Those with learning memory of cognitive dimensions were the majority. Psychodynamic and social dimensions were less memorable compared to cognitive dimension. Similarly, students seemed to remember more positive emotional and social experiences than negative ones, meaning that positive emotional and social dimensions are more long lasting. These findings compare favourably to the standard Tripod surveys of quality teaching common in USA, UK and China [25]. Other researchers have also concurred that cognitive learning dimensions are more memorable [25, 24, 27].

Findings from this study shows that students in JKUAT Juja campus in the January - April 2015 Semester have the competence to understand quality teaching based on the notion they had of an ideal teacher as a person who is well prepared, having the skills to help the student to learn, and being equipped with knowledge of the discipline. This observation is found in the unstructured feedbacks that clearly shown that students were able to explain in their own words the characteristics that they believed described effective teaching. The same finding is also observed in the structured feedback with a set of prescribed characteristics of either agree or disagree options. In the structured feedback, students used various adjectives to described characteristics of what they thought was effective teaching including characteristics such as presence of tutors who are competent and knowledgeable in their field. Other characteristics included tutor's ability to teach in a steady pace that ensures that students learn and understand subject matter. Other characteristics include tutor's ability to explain the content of the subject, ability to follow up and handle every student, punctuality, precise, audible etc. These findings concur with findings by Delaney, Johnson, Johnson, \& Treslan [24] who established that effective university teachers at Memorial University are: respectful, knowledgeable, approachable, engaging, communicative, organized, responsive, professional, and humorous. Similar adjectives have also being used by students in this study, clearly illustrating that student can differentiate high quality teaching from sloppy engagements. These studies clearly show that Student feedbacks are good tools to measure teaching qualities; after all, no one knows more about what happens in classrooms than the students and teachers who inhabit them [25].

\subsubsection{Student's Awareness on Faculty Employment Statuses}

The stage theory of higher education development proposed by Professor Martin Trow at the University of California [23] explains why the composition of faculty in Universities and other Higher Education Institutions is shifting in favour of part-time faculty. With a paradigm shift in higher education from elite to mass education that allows universal student access to education, there is a sharp increase in the number of people who can receive higher education. Equally, there is a change in the faculty composition, diversity of teaching purposes and forms of Education, and curriculum set-up. Thus Universities have to recruit more staff.

Academic titles seemed not to be clear to students. This findings were observed in both the qualitative data as well as in the quantitative data. Generally, students were able to differentiate senior faculty member from junior faculty members. The academic title of Associate Professor is unknown to students. Perhaps because Associate Professors and Full Professors are all referred to as Professor. The rank of Senior Lecturer and Assistant Lecturer are not well known, thus students know faculty members as either Professor, Lecturer or Graduate Assistant; especially for those faculty members without $\mathrm{PhD}$. This knowledge enabled students to evaluate performance by faculty under different employment terms. A previous study in Canada shown that students have the competence to profile staff on the basis of academic titles [35].

A study by Bippus, Brooks, Plax, \& Kearney [36] shown that faculty employment status is not a salient issue to students. Similarly observations were made in this study. 
Students acknowledged that part-time faculty is present in JKUAT. Majority are of lower academic qualification and they are more difficult to find compared to full-time staff. Worldwide the trend towards the engagement of part-time faculty in Higher Education Institutions (HEIs) is increasing. This is partly explained by the pressure on higher education institutions to reduce costs $[40,41,42,7]$, and partly by lack of qualified faculty in the market. Hence HEIs have to share the faculty available in the market and since it's a crime for anybody to hold two permanent jobs in Kenya, then faculty end up working on part-time basis in various places. Public Universities get funding from the Government. Currently many Governments are experiencing financial challenges and have reduced funding allocation to public institutions. Thus a large number of post-secondary institutions are currently struggling to finance their operations and are frantically trying various options to reduce their costs. This is not only limited to institutions in Kenya but seems to the worldwide problem. This has resulted in substantial increase in the number of part-time faculty in HEIs [21].

The demand for high quality full-time faculty members outstrips supply. It takes over 20 years of training to produce a professor. This period is very long, beside diseases like HIV AIDS have hit the productive age of the society and have impacted negatively on HEIs. Universities are forced to hire part-time faculty to mitigate the gap. Sometimes hiring of the part-time faculty is done in rush and fails to ensure quality control measures are put in place. In some private Universities, part-time faculty is so frequent that student may not even differentiate full-time staff from part-time [49]. Thus part-time faculty in likely to be a permanent feature in HEIs faculty structuring.

\subsubsection{Effects of Faculty Employment Statuses on Their Teaching Quality}

Previous studies have shown that faculty employment status influence their organizational commitment, job satisfaction performance [66, 67, 68, 69]. Indeed, some staffs are on record of having to hold on exams scripts and marks until their payments are processed. Findings from this study show that employment status affect faculty performance in a number of ways. First students pointed out that majority parttime faculty are recent graduates who perhaps may lack experience and this could explain why student reported that they find them mostly unprepared and are inferior to fulltime faculty when it comes to content delivery.

These findings are in congruency with previous studies by Percy and Beaumont [39], who also established the major factors that determine who is recruited as a part-time faculty include the task to be carried out and who is available locally - the insecure contract and level of reward make this a distinctly local labour market, and the recruitment process is frequently "casualised" and informal too. Thus in researchintensive Universities, a plentiful supply of postgraduate research students and contract researchers results in their making up a large proportion of sessional staff available in the market.
Part-time faculty in JKUAT Juja campus have no offices and students indicated that they do not know where to find them. This makes part-time faculty inaccessible and unavailable to mentor students. In addition, their competence is wanting and are unlikely to have the capacity to mentor the students even if they wanted to mentor them. These findings resonate well with the findings by Vegas \& De Laat [50]who established that part-timer faculty either have low effect on student learning or negatively impact student outcomes This is especially demonstrated in units with research project where students require experienced staff to the supervise them. Students find the part-timers inaccessible and incapable of supervising them. In the end the students end up working with the few full-time staff available in the University. At this juncture students are able to differentiate faculty members on the basis of their employment status.

Part-time faculty have no time for extra-class communication and in the event that they miss a lecture, it is very difficult for them to organize a makeup class. The life of part-time faculty is very difficult. Their mode of employment is very casual and they crisscross from institution to institution in order to enhance their take home [37]. They have no facilities to cushion them in the event of any adversities. Obviously, working in such a fluid environment is unlikely to make anyone motivated enough to demonstrate any form of organizational commitment and job satisfaction $[66,67,68,69]$. This in end will affect their performance.

It is important to note that part-time faculty is going to remain a permanent feature in the education sector in Kenya. It is not an idea that we can wish away and close our eyes and assume that it does not exist or it's going to pass. Stakeholders in the education sector must find ways of enhancing the teaching quality delivered by part-time faculty. Usually, part-timer faculty are not given opportunities to develop professionally [9] and they face the insecurity of lack of employment and the dilemma between the need to earn an income while attending to their personal development. This drives them to work in many places at the same time $[10,11]$. Part-time faculty are likely to offer post better teaching quality if the HEIs design some form of continuous development programmes that make them feel part of the bigger system.

\subsection{Conclusion}

\subsubsection{Students Perception on Quality Teaching}

Students in JKUAT Juja campus have memory of high quality learning experiences that has occurred at some point in their life. They remember mostly cognitive dimensions of quality teaching, but also do remember the positive psychodynamic and social dimension of quality teaching. Their notion of an ideal teacher is a person who is well prepared, having the skills to help the student to learn, being equipped with knowledge of the discipline, able to follow up and handle every student, very punctual, precise and audible. Students demonstrated that they have competence to identify 
a good teacher and could differentiate high quality teaching from low quality teaching.

\subsubsection{Student's Awareness on Faculty Employment Statuses}

Students demonstrated low competence in understanding academic titles. Very few of them knew Associated Professor and a small majority knew the difference between Senior Lecturer and Lecturer. However, they were able differentiated senior faculty members from junior faculty members and also part-time faculty from full time faculty. Therefore, students are competent source of information on faculty under different employment statuses, after all they are the ones who spend the highest amount of time in the classroom and have more moments of truth with faculty than any other stakeholder in the education sector.

\subsubsection{Effects of Faculty Employment Statuses on Their Teaching Quality}

Majority of part-time faculty are recent graduates who lack teaching experience. Thus students found them mostly unprepared and of inferior teaching quality compared to full-time faculty when it comes to content delivery. Parttime faculty in JKUAT Juja campus have no offices and students do not know where to find them. This makes them inaccessible and unavailable to carry out student mentorship functions. Students find the part-timer faculty unavailable to supervise them. Part-time faculty have no time for extra-class communication and in the event that they miss a lecture, it is very difficult for them to organize a makeup class.

\subsection{Recommendations}

\subsubsection{Recommendations for Improvement}

i. Students Perception on Quality Teaching?

Faculty members should be trained on pedagogy to understand that students are more interested in learning experiences that have cognitive dimensions in nature. They should also know that students are interested more in positive psychodynamic and social dimensions of quality teaching. Faculty members should understand the students' notion of an ideal high quality teacher and conform to it. These are the areas they should focus on so as to deliver memorable high quality teaching episodes.

ii. Student's Awareness on Faculty Employment Statuses

Faculty should have well labelled offices with insignias of their academic titles. This should be well done and detailed; for example: Prof. Michael Arap Sang, Associate Professor in Chemistry or Dr Peter M. Maundu, Senior Lecturer in Communication Studies, etc. This will help students figure out the academic titles of the faculty members. In addition, the insignia should indicate whether the faculty is full-time or part-time.

iii. Effects of Faculty Employment Statuses on their Teaching Quality

The hassling nature of the life of part-time faculty due to the casual nature of their engagement with the University impact negatively on their delivery. In order to improve the quality of teaching delivered by part-time faculty, the University should consider some improvements in their welfare. This will include adequate and prompt remuneration, provision of comfortable working space and exposure in to continuous professional development programmes. Also the University should put in mechanism to monitor teaching by part-time lecturers

\subsubsection{Recommendations for Further Studies}

This study proposes further study on the allegation that Graduate Assistants are allowed to teach and examine student since this is a serious allegation that should not be left at face value. In carrying such a study, the researcher should focus on interviewing both students and faculty and perhaps do so in a wider scope including both in public and private University.

\section{References}

[1] G. Gibb, Dimensions of quality, Higher Education Academy, 2010 .

[2] L. Harvey, A. Burrows and D. Green, "Criteria of quality in Higher Education of the QHE Project," 1992.

[3] D. Chalmers, A review of Australian and international quality systems and indicators of learning and teaching, Australia: Carrick Institute for Learning and Teaching in Higher Education, 2007.

[4] R. G. Baldwin and J. L. Chronister, Teaching without tenure: policies and practices for a new era, Baltimore, MD: Johns Hopkins, 2001.

[5] C. Leatherman, "Part-timers continue to replacefull-timers on college faculties," The Chronicle of Higher Education, p. 18, 2001 .

[6] K. S. Mangan, "Many colleges fill vacancies with part-time professors, citing economy and uncertainty about enrollments. Chronicle of Higher Education," Chronicle of Higher Education, pp. 9-11, 1991.

[7] M. Kilungu, "Personal characteristics and organizational commitment of part-time academic staff in institutions of higher education in Nairobi and Mombasa Cities in Kenya," International Journal of Social Sciences and Entrepreneurship, vol. 1, no. 12, p. 66, 2014.

[8] C. Bryson, "What about the workers? The expansion of Higher Education and the Transformation of Academic work," Industrial Relations Journal, vol. 35, no. 1, pp. 38 57, 2004.

[9] J. Gappa, A. Austin and A. and Trice, "Rethinking Academic Work and Workplaces," Change Management Journal, vol. 37, no. 6 , pp. $32-39,2005$.

[10] J. Allen - Collinson and J. Hockey, "Capturing Contracts: Informal activity among contract researchers," British Journal of Sociology of Education, vol. 19, no. 4, pp. 497 - 515, 1998.

[11] C. Bryson, "More is less: Contract Research in UK higher education institutions," in EASST Conference, Lisbon, 1998. 
[12] R. Wilson, L. Wood and J. Gaff, "Social-psychological accessibility and faculty student interaction beyond the classroom," Sociology of Education, vol. 47, pp. 74-92, 1974.

[13] W. Hussar and T. Bailey, "Projections of Education Statistics to 2013," U.S. Government Printing Office, Washington, D. C, 2013.

[14] Economist, 2005. [Online]. Available: www.economist.com. [Accessed 8th October 2014].

[15] E. Sall, "Alternative Models to Traditional Higher Education: Market Demand, Networks, and Private Sector Challenges," Journal of Higher Education in Africa, vol. 2, no. 1, p. 177 212., 2004.

[16] W. G. Tierney, "Forms of privatisation: Globalisation and the changing nature of tertiary education.," in Globalisation and the tertiary education in the Asia-Pacific: The changing nature of a dynamic market, Toh Tuck Link, Singapore, World Scientific, 2010, pp. 163-200.

[17] J. Z. Nyangau, "Higher Education as an Instrument of Economic Growth in Kenya," FIRE: Forum for International Research in Education, vol. 1, no. 1, p. Article 3, 2014.

[18] N. A. Owuor, "Higher education in Kenya: The rising tension between quantity and quality in the post-massification period," Higher Education Studies, vol. 2, no. 4, pp. 126-136, 2012.

[19] J. G. Cross and E. N. Goldenberg, Off-track profs: Nontenured teachers in higher education, Cambridge, MA: MIT Press, 2009.

[20] P. D. Umbach, "How effective are they? Exploring the impact of contingent faculty on undergraduate education," Review of Higher Education, vol. 30, no. 2, 2007.

[21] S. Zhang and N. An, "Analysis on the Concepts and Theories of the Quality of Graduate Education.," Asian Social Science, vol. 6 , no. 12 , pp. $1-4,2010$

[22] J. Schuster and M. Finkelstein, Schuster, J. H. \& Finkelstein, M. J. (2006). The American faculty: The restructuring of academic work and careers., Baltimore, MD: The John Hopkins University Press, 2006.

[23] A. Lindsay, "Concepts of quality in higher education," Journal of Tertiary Education Administration, vol. 14, no. 2, pp. 153-163, 1992.

[24] M. Trow, "From Mass Higher Education to Universal Access: The American Advantage," Research and Occasional Paper Series: CSHE.1.00, Spring 2000.

[25] J. Delaney, A. Johnson, T. Johnson and D. Treslan, "Students' Perceptions of Effective Teaching in Higher Education, Faculty of Education, Memorial University of Newfoundland, USA," 2010. [Online]. [Accessed 1st November 2014].

[26] R. F. Ferguson, "Student Perceptions of Teaching Effectiveness," Harvard University, 2010. [Online]. Available: www.harvard.edu. [Accessed 1 Nov 2014].

[27] C. McNaught, D. Leung and D. Kember, "Report on the Student Engagement Project.," Hong Kong, 2006.

[28] K. J. Rowe, "The importance of teacher quality as a key determinant of students "experiences and outcomes of schooling"," in Conference Proceedings 2003, Melbourne, Australia, 2003.
[29] E. Ralph, Effective college teaching: Fresh insights and exemplary practices, New York: Nova Science, 2003.

[30] I. M. 2. Shamos, Handbook of Faculty Titles, Pittsburgh, PA 15213: Carnegie Mellon University, 2002.

[31] J. Kertzer, Poetic Justice and Legal Fictions, Cambridge University Press, 2010.

[32] G. Webb, Making the most of appraisal: career and professional development planning for lecturers, Routledge, 1994, p. 30.

[33] ASPC Procedures, "Promotion of Chairs and Readerships in the Open University, ASPC Procedures 2010 Promotion of Chairs and Readerships in the Open University," 2010. [Online]. Available: www.open.ac.uk/foi/main/sites/www.open.ac.uk.foi.main/files/pics/ d120257.pdf.. [Accessed 3rd March 2015].

[34] HUPP, "Handbook of University Policies and Procedures at The University of Queensland," 2015. [Online]. Available: http://ppl.app.uq.edu.au/. [Accessed 3rd March 2015].

[35] Academic Staff Agreement, "Schedule A: Salaries and Casual Rates," $2014 . \quad$ [Online]. Available: http://www.hr.uwa.edu.au/policies/eb/collective-agreements. [Accessed 3rd March 2015].

[36] K. .. P. Lundy and B. D. Warme, "Part-timefaculty: Student perceptions and experiences," TheCanadian Journal of Higher Education, vol. 19, pp. 73-85., 1989.

[37] A. Bippus, C. F. Brooks, T. Plax and P. Kearney, "Students' Perceptions of Part-time and Tenured/Tenure-Track Faculty: Accessibility, Mentoring, and Extra-Class Communication," Joumal of the Association for Commununication Administration, vol. 30, pp. 13-23, 2001.

[38] C. Bryson, "Supporting sessional teaching staff in the UK - to what extent is there real progress?," Journal of University Teaching \& Learning Practice, vol. 10, no. 3, 2013.

[39] R. May, "Casualisation here to stay? The modern university and its divided workforce," in Dialogue Down under, Association of Industrial Relations Academics of Australian and New Zealand (AIRAANZ) Conference, 2-4 February, Aucklan, 2011.

[40] A. Percy and R. Beaumont, "The casualisation of teaching and the subject at risk," Studies in Continuing Education, vol. 30, no. 2, pp. 145-157, 2008.

[41] D. Leslie, "Part-time, adjunct, and temporary faculty: The new majority?," in The Sloan Conference on Part-Time and Adjunct Faculty., 1998.

[42] R. G. Baldwin and M. R. Wawrzynski, "Contingent faculty as teachers: What we know; What we need to know," American Behavioral Scientist, vol. 55, no. 11, pp. 1485-1509, 2011.

[43] E. Bettinger and B. T. Long, "Does cheaper mean better? The impact of using adjunct instructors on student outcomes," The Review of Economics and Statistics, vol. 92, no. 3, pp. 598613, 2010.

[44] IRHEPC, " Independent Review of Higher Education Pay and Conditions," Stationery Office, Norwich, 2005.

[45] C. Husbands, "Assessing the use of part-time teachers in British Higher Education: Problems and issues in enumerating a flexible labour force," Higher Education Quarterly, vol. 52, no. 3, pp. 257-282, 1988. 
[46] J. Enders, "Academic staff in Europe: changing employment and working conditions," in Academic work and life, Amsterdam, JAI, 2000.

[47] M. Kimber, "The tenured 'core' and the tenuous 'periphery': the casualisation of academic work in Australian universities," Journal of Higher Education Policy and Management, vol. 25, no. 1, pp. 41-50, 2003.

[48] CHE, "Handbook on Process for Quality Assurance in Higher Education in Kenya," CHE Publishing, Nairobi, 2008.

[49] Republic of Kenya, "Kenya Vision 2030," Government Printer., Nairobi, 2007.

[50] K. Mwiria and J. Currey, Public and private universities in Kenya, Nairobi: Oxford East African Educational Publishers, 2007.

[51] E. Vegas and J. De Laat, "Do differences in teacher contracts affect student performance? Evidence from Togo," World Bank, Washington DC, 2003.

[52] C. C. Barnabas, "The Evolution of Quality Assurance in Higher Education," Faculty Working Papers from the School of Education, 2007.

[53] C. H. Haskins, The Rise of Universities, Cornell University Press, 1957, p. 107.

[54] W. K. Selden, Accreditation: A struggle Over Standards in Higher Education., New York: Harper and Brothers, 1960, p. 130 .

[55] R. Hofstadter, The Development of Academic Freedom in the United States, New York: Columbia University Press, 1981.

[56] T. A. Joiner and S. Bakalis, "The antecedents of organizational commitment: the case of Australian casual academics," International Journal of Educational Management, vol. 20, no. 6, pp. 439 - 452, 2006.

[57] A. Borchers and J. Teahen, "Organizational commitment of part-time and distance faculty," in AMCIS 2001 Proceedings. Paper 41, 2001.

[58] S. Shaw and C. Ogilvie, "Making a virtue out of a necessity: Part time work as a site for undergraduate work-based learning," Journal of European Industrial Training, vol. 34, no. (8/9), pp. 805-821, 2010.

[59] M. K. Eagan and A. J. Jaeger, "Closing the gate: Part-time faculty instruction in gatekeeper courses and first-year persistence," New Directions for Teaching and Learning, vol. 115, p. 39-54, 2008.

[60] P. D. Umbach, "The effects of part-time faculty appointments on instructional techniques and commitment to teaching," in 33rd Annual Conference of the Association for the Study of Higher Education, Jacksonville, FL, 2008.

[61] C. Bryson and R. Blackwell, "Managing temporary workers in higher education: Still at the margin?," Personnel Review, vol. 35, no. 2, pp. 207-224, 2006.

[62] L. C. Chuan, "A critical review of commitment studies: a call for research in Sarawak school settings," Journal Penyelidikan, vol. 6, pp. 75-76, 2005.

[63] A. A. Chungtai and S. Zafar, "Antecedents and consequences of organizational commitment among Pakistani university teachers," International Journal of Manpower, vol. 19, no. 3, pp. 184-194, 2006.

[64] M. Laka-Mathembula, "Modelling the relationship between organizational commitment, leadership style, human resource management practices and organizational trust," Unpublished PhD Thesis, Pretoria, RSA, 2004.

[65] E. Ura, "Advocating student evaluation of teachers in higher education in Nigeria: A pilot study," 2011, p. 55.

[66] M. Menya, "Quality Management of the Postgraduate Programs in the Faculty of Management Studies at Islamic University in Uganda (IUIU) - A Case Study," in Challenges for faculty management at African higher education institutions, Osnabriick, 2011 Postfach 1940, 49009 Osnabriick, University of Applied Sciences Publishers, 2011, p. 33.

[67] K. Mburu, P. Gathia and J. Kwasira, "An insight into motivational strategies in enhancing academic staff job satisfaction in selected public Universities in Kenya (A survey of Nakuru County)," Int. J. Mgmt Res. \& Bus. Strat, 2014.

[68] J. Obwogi, "Factors that Affect Quality of Teaching Staff in Universities in Kenya," Unpublished PhD Thesis, Juja, Kenya, 2011.

[69] D. J. Kipkebut, "Organizational commitment and Job satisfaction in higher educational institutions: the Kenyan case," Unpublished Ph D thesis, London, 2010.

[70] E. K. Kamaara, "Towards a Culture of Quality Management at SASS, Moi University: Changing lecturers' Attitudes to Student Assessment/QM," in Challenges for faculty management at African higher education institutions, Osnabriick, 2011 Postfach 1940, 49009 Osnabriick, University of Applied Sciences Publishers, 2011, p. 15.

[71] G. V. Glass and K. D. Hopkins, Statistical Methods in Education and Psychology, 2nd ed ed., Englewood Cliffs, N. J.: Prentice-Hall, 1984.

[72] W. G. Cochran, Sampling techniques, 3rd ed., New York:: John Wiley \& Sons, 1977.

[73] C. Kothari, Research Methodology: Methods and Techniques, New Delhi: New Age International Publishers, 2009.

[74] R. V. Krejcie and D. W. Morgan, "Determining sample size for research activities," Educational and Psychological Measurement,, vol. 30, pp. 607-610., 1970.

[75] A. Bryman, "The debate about quantitative and qualitative research: a question of method or epistemology?," The British Journal of Sociology, vol. 35, pp. 75-92, 1984.

[76] J. Aronson, "A pragmatic view of thematic analysis," The Qualitative Report, vol. 2, pp. 1-3., 1994.

[77] K. M. Watty, "Quality in accounting education: what say the academics?," Quality Assurance in Education, vol. 13, no. 2, pp. $120-131,2005$.

[78] C. Ball, "Fitness for purpose," in Essays in higher education, SRHE \& NFER-Nelson, 1985.

[79] D. Woodhouse, "The quality of quality assurance agencies," Quality in Higher Education, vol. 2, no. 10, pp. 77 - 87, 2004.

[80] L. Vidovich, "That chameleon quality: the multiple and contradictory discourses of 'quality' policy in Australian higher education," Discourse, vol. 22, no. 2, 2001. 
[81] D. N. Sifuna, "Some reflections on the expansion and quality of higher education in public universities in Kenya.," Research in Post-Compulsory Education, vol. 15, no. 4, p. 415 425, 2010.

[82] D. Bloom, "Globalization and Education: An Economic Perspective," in Globalization, Culture and Education in the New Millennium, Berkeley, California University Press, 2005, p. $56-77$.

[83] P. Altbach, L. Reisberg and L. E. Rumbley, "Trends in Global Higher Education: Tracking an Academic Revolution," UNESCO, Paris, 2009.

[84] C. Ngome, "Kenya," in African Higher Education: An International Reference Handbook, Bloomington, Indiana University Press, 2003, pp. 359-371.

[85] I. O. Oanda and J. Jowi, "University expansion and the challenges to social developments in Kenya: Dilemmas and pitfalls," Journal of Higher Education in Africa, vol. 10, no. 1, pp. 49-71, 2012.

[86] G. Banachowski, "Perceptions of chief academic officers atcommunity colleges regarding employment and utilization of part-time faculty," Community College Review, p. 254, 2009.

[87] D. Jacoby, "Effects of part-time faculty employment on community college graduation rates," Journal of Higher Education, vol. 77, pp. 1081-1103, 2006.

[88] J. Eagan and A. J. Jaeger, "Unintended consequences: Examining the effect of part-time faculty members on associate's degree completion," Community College Review, vol. 36, p. 167, 2009.

[89] F. Marton, "What does it take to learn?," in How Students Learn, IRDPCE, Univ. of Lancaster, 1975.

[90] L. Harvey and D. Green, "Defining quality," Assessment and Evaluation in Higher Education, vol. 18, pp. 8-35, 1993.

[91] A. Stevenson, Oxford Dictionary of English, 3 ed., London: Oxford University Press, 2010.

[92] J. Biggs, "The reflective institution: assuring and enhancing the quality of Teaching and learning.," Journal of Higher Education, vol. 41, pp. 221-238, 2001.

[93] P. M. Shields and N. Rangarajan, A Playbook for Research Methods: Integrating Conceptual Frameworks and Project Management, Stillwater, OK, USA: New Forums Press, 2013.

[94] S. Lohr, Sampling: Design and Analysis, 2nd, Ed., New York: MPS ltd, A Macmillan Company., 2010.

[95] P. Schloss and M. Smith, Conducting Research, NJ: Prentice Hall, 1999.

[96] R. Czaja, "Questionnaire Pretesting Comes of Age," Marketing Bulletin, vol. No. 9, no. Article 5, pp. 52-66, 1998.

[97] R. E. Boyatzis, Transforming qualitative information: Thematic analysis and code development, London: Sage Publications, Inc., 1998.

[98] J. Fereday and E. Muir-Cochrane, "Demonstrating rigor using thematic analysis: A hybrid approach of inductive and deductive coding and theme development," International Journal of Qualitative Methods, vol. 5, no. 80, 2008.

[99] M. B. Miles and A. M. Huberman, Qualitative data analysis: An expanded sourcebook, Thousand Oaks: Sage publications, Inc., 1994.

[100] N. Ritter, "Understanding a widely misunderstood statistic: Cronbach's alpha," in Southwestern Educational Research Association (SERA) Conference 2010, New Orleans, LA, 2010.

[101] D. George and P. Mallery, SPSS for Windows step by step: A simple guide and reference. 11.0 update, 4th ed ed., Boston: Allyn \& Bacon, 2003.

[102] IBM Corp. Released, IBM SPSS Statistics for Windows, Version 21.0 ed., Armonk, NY: IBM Corp, 2012.

[103]K. Illeris, The three dimensions of learning: Contemporary learning theory in the tension field between the cognitive, the emotional and the social, Leicester: NIACE, 2004.

[104]A. B. Costello and J. W. Osborne, "Best practices in exploratory factor analysis: four recommendations for getting the most from your analysis," Practical Assessment, Research \& Evaluation, vol. 10, no. 7, pp. 1-9, 2005. 